\title{
Article/Artigo
}

\section{Evaluation of inadequate anti-retroviral treatment in patients with HIV/ AIDS}

\author{
Avaliação do uso inadequado de antirretrovirais no tratamento de pacientes com HIV/AIDS
}

\section{Leonardo Carvalho da Fonseca ${ }^{1}$, Francislene Juliana Martins ${ }^{2}$, Rita de Cássia Padula Alves Vieira ${ }^{1}$, Rouzeli Maria Coelho Pereira ${ }^{3}$, Aline Siqueira Ferreira ${ }^{4}$ and Nádia Rezende Barbosa Raposo ${ }^{1,2}$}

\begin{abstract}
Introduction: Since the emergence of antiretroviral therapy, the survival of patients infected with human immunodeficiency virus has increased. Non-adherence to this therapy is directly related to treatment failure, which allows the emergence of resistant viral strains. Methods: A retrospective descriptive study of the antiretroviral dispensing records of 229 patients from the Center for Health Care, University Hospital, Federal University of Juiz de Fora, Brazil, was conducted between January and December 2009. Results: The study aimed to evaluate patient compliance and determine if there was an association between non-adherence and the therapy. Among these patients, $63.8 \%$ were men with an average age of $44.0 \pm 9.9$ years. The most used treatment was a combination of 2 nucleoside reverse transcriptase inhibitors with 1 non-nucleoside reverse transcriptase inhibitor (55.5\%) or with 2 protease inhibitors $(28.8 \%)$. It was found that patients taking lopinavir/ritonavir with zidovudine and lamivudine had a greater frequency of inadequate treatment than those taking atazanavir with zidovudine and lamivudine ( $85 \%$ and $83.3 \%$, respectively). Moreover, when the combination of zidovudine/ lamivudine was used, the patients were less compliant $\left(\chi^{2}=4.468,1\right.$ degree of freedom, $\mathrm{p}=$ $0.035)$. Conclusions: The majority of patients failed to correctly adhere to their treatment; therefore, it is necessary to implement strategies that lead to improved compliance, thus ensuring therapeutic efficacy and increased patient survival.
\end{abstract}

Keywords: Acquired immunodeficiency syndrome. Medication adherence. Anti-retroviral agents

\section{RESUMO}

Introdução: A partir do surgimento da terapia antirretroviral, o paciente soropositivo teve sua sobrevida aumentada. A não adesão a essa terapia está relacionada diretamente à falência terapêutica, a qual propicia o aparecimento de cepas virais mais resistentes. Métodos: Foi realizado um estudo retrospectivo e descritivo dos registros de dispensação de antirretrovirais de 229 pacientes do Centro de Atenção à Saúde do Hospital Universitário da Universidade Federal de Juiz de Fora, no período de janeiro a dezembro de 2009. Resultados: Tal estudo teve por objetivo avaliar a adesão do paciente ao tratamento e se houve associação entre a não adesão e a terapêutica. Desses pacientes, $63,8 \%$ eram do sexo masculino e apresentavam idade média de 44,0 $\pm 9,9$ anos. Foram realizados 28 esquemas terapêuticos diferentes. Dentre esses, os mais utilizados foram aqueles que combinavam 2 inibidores da transcriptase reversa análogos de nucleosídeos/nucleotídeos com 1 inibidor da transcriptase reversa não análogo de nucleosídeo $(55,5 \%)$ ou com 2 inibidores de protease $(28,8 \%)$. Foi verificado que os pacientes em uso de lopinavir/ritonavir ou atazanavir associados à zidovudina e lamivudina apresentaram maiores frequências de tratamento considerado inadequado ( $85 \%$ e $83,3 \%$, respectivamente). Além disso, quando a combinação zidovudina/lamivudina esteve presente no esquema medicamentoso, os pacientes aderiram menos ao tratamento $(\chi 2=4,468$; grau de liberdade $=1$; $p=0,035)$. Conclusões: A maioria dos pacientes realizava tratamento considerado inadequado. Portanto, é necessário implementar estratégias que conduzam à melhoria da adesão ao tratamento, a fim de garantir eficácia terapêutica e aumento da sobrevida do paciente.

Palavras-chaves: Síndrome da imunodeficiência adquirida. Adesão à medicação. Agentes antirretrovirais.

1. Faculdade de Farmácia, Universidade Federal de Juiz de Fora, Juiz de Fora, MG. 2. Serviço de Informação Tóxico-Farmacológica, Centro de Atenção à Saúde, Hospital Universitário, Universidade Federal de Juiz de Fora, Juiz de Fora, MG. 3. Centro de Atenção à Saúde, Hospital Universitário, Universidade Federal de Juiz de Fora, Juiz de Fora, MG. 4. Faculdade de Medicina, Universidade de São Paulo, São Paulo,SP. Adddress to: Dra Nádia Rezende Barbosa Raposo. Endereço: Rua José Lourenço Kelmer s/n, Campus Universitário, Laboratório NIQUA, Bairro São Pedro, 36036-900 Juiz de Fora, MG, Brasil. Phone: 5532 2102-3809

e-mail: nadiafox@gmail.com

Received in 08/04/2011

Accepted in 30/09/2011

\section{INTRODUCTION}

Treatment with antiretroviral drugs of people infected with Human Immunodeficiency Virus/Acquired Immunodeficiency Syndrome (HIV/AIDS) associated with the prevention and control of infection have improved significantly changes in mortality rates and life expectancy among HIV-positive individuals ${ }^{1}$ (esta frase foi modificada). For any therapy to succeed, it is necessary that patients are aware of the importance of their adherence to their pharmacological treatment ${ }^{2}$. The incorrect use of antiretroviral drugs is related to treatment failure by the emergence of viral strains that are resistant to the drugs used ${ }^{3}$.

According to the Brazilian Ministry of Health, adherence may be construed as a multifactorial and dynamic aspect that involves physical, psychological, social, cultural, and behavioral factors. It requires the integration of the patient, health professionals, and social network by establishing the responsibilities of each in the process and helping to promote self-care ${ }^{4}$.

Low adherence to drug therapy is a public health problem because it increases the risk of developing drug resistance, and adverse effects may occur following the abrupt cessation of therapy or the occurrence of toxicity by drug overuse $\mathrm{e}^{5,6}$.

Dias $^{7}$ and Faustino and Seidl ${ }^{8}$ considered that the complexity of the regimen and the low educational level of patients decrease the ability of patients to cope with treatment difficulties, which can lead to rejection of their seropositivity. Moreover, the adverse effects of antiretroviral medications, poor patient relationship with health professionals, difficulties in adapting to the daily routine of drug therapy, and alcohol and drug use are also considered risk factors for poor adherence to drug treatment.

Non-adherence can be found in several forms and highlights the failure to fully or partially follow the prescriptions and the interruption or discontinuation of treatment, as well as excessive drug intake ${ }^{5}$. Although there is no standard for assessing adherence to ART, there are several approaches that may assist in its evaluation. These 
approaches include self-reported assessments through medical records, number of pills distributed, drug plasma concentration measurements, and dispensing pharmacy records ${ }^{9}$.

In the City of Juiz de Fora, Minas Gerais, there are 2 antiretroviral dispensing units (ADUs): the Serviço de Assistência Especializada de Juiz de Fora (Specialized Care Unit in Juiz de Fora) and the Centro de Atenção à Saúde do Hospital Universitário, Universidade Federal de Juiz de Fora (Center for Health Care at the University Hospital, Federal University of Juiz de Fora) (HU/CAS/UFJF). Within the context of adherence to ART, this study aimed to evaluate the factors that affect adherence, the focus on drug therapy, and the prevalence of inadequate treatment (i.e., irregular adherence and dropout).

\section{METHODS}

We conducted a retrospective and descriptive study that analyzed the antiretroviral drug distribution log from the HU/CAS/UFJFADU.

All patients seen in this ADU were included. They comprised 229 patients who were assisted between January and December 2009. The inclusion criteria were (1) age over 18 years and (2) maintenance on the same drug regimen during this period. We excluded pregnant women and patients who died during the study period.

From the model, which was adapted from Gomes et al. ${ }^{9}$, patients that did not adhere to therapy or who did not acquire their drugs at the appropriate time were classified as receiving inadequate treatment, which could be described as: a) irregular adherence, i.e., the interval between collecting medication was $>34$ days, considering that the drugs are distributed for 30 days; and b) treatment dropout, i.e., not collecting medication for $>2$ months.

We also analyzed gender, age, and current drug regimen. For patients receiving inappropriate treatment, we evaluated their pharmacological therapy. We checked if there was an association between treatment compliance and drug therapy.

Variables were evaluated with the aid of the Statistical Package for Social Sciences, version 14.0. Association analyses (chi-square test, $\chi^{2}$ ) were made from the type of treatment (adequate or inadequate) and the other variables. The significance value was 0.05 .

\section{Ethical considerations}

This project was approved by the Ethics Committee of the Federal University of Juiz de Fora (No. 299/2009, CAAE 0187.0.180.000-09).

\section{RESULTS}

We evaluated 229 patients undergoing pharmacological treatment for HIV between January and December 2009. Of this total population, $63.8 \%(\mathrm{n}=146)$ were male and $36.2 \%(\mathrm{n}=83)$ were female, with an average age of $44.0 \pm 9.9$ years.

Regarding the assessment of medication adherence, $72.9 \%$ $(n=167)$ of patients received inappropriate treatment, characterized by irregular adherence or therapy abandonment, while $27.1 \%$ $(\mathrm{n}=62)$ underwent appropriate treatment and were considered adherent to the prescribed drug therapy.

Gender analysis, when used as an adherence function to treatment, showed that $73.3 \%(\mathrm{n}=107)$ of men had inadequate treatment, while for females, this figure was $72.3 \%(n=60)$; no statistically significant difference was observed $\left(\chi^{2}<0.001\right.$, degrees of freedom $=1, \mathrm{p}=0.993$ ).
No association was found between adherence and patient age (Table 1).

TABLE 1 - Patient adherence to ART by age group at the Center for Health Care, University Hospital, Federal University of Juiz de Fora.

\begin{tabular}{lcc}
\hline Age (years) & $\begin{array}{c}\text { Appropriate } \\
\text { treatment \% }\end{array}$ & $\begin{array}{c}\text { Inadequate } \\
\text { treatment \% }\end{array}$ \\
\hline$\leq 30$ years & 8.3 & 91.7 \\
\hline $31-50$ & 29.2 & 70.8 \\
\hline$>50$ & 25.0 & 75.0 \\
\hline
\end{tabular}

ART: antiretroviral therapy; $\chi^{2}: 2,623$; degrees of freedom: $2 ; \mathrm{p}=0.269 ; \mathrm{n}=229$.

Twenty-eight different drug combinations were found, and of those, 11 consisted of zidovudine/lamivudine (AZT/3TC) in combination with other drugs. In addition, 19 of them were triple combinations, 7 with a combination of 4 drugs, and 2 with 5 combinations. The most used therapy was the combination of efavirenz (EFV) and AZT/3TC (34.1\%, n = 78), followed by lopinavir/ritonavir (LPV/r) combined with AZT/3TC (17.5\%, $\mathrm{n}=40)$. Other frequently used therapies were EFV plus $3 \mathrm{TC}$ and tenofovir (TDF) $(8.3 \%, \mathrm{n}=19)$, nevirapine (NVP) in combination with AZT/3TC $(7.9 \%, \mathrm{n}=18)$, 3TC combined with LPV/TDF $(6.6 \%, \mathrm{n}=15)$, and atazanavir (ATV) with AZT/3TC $(5.2 \%, \mathrm{n}=12)$ (Table 2). The other 22 therapies were prescribed to $<10$ patients, and among them, 14 were used for only 1 patient.

TABLE 2 - Distribution of patients on ART according to pharmacological therapy.

\begin{tabular}{lcc}
\hline Treatment & Number & Percentage \\
\hline Efavirenz + (zidovudine + lamivudine) & 78 & 34.1 \\
\hline Lopinavir/ritonavir + (zidovudine + lamivudine) & 40 & 17.5 \\
\hline Efavirenz + lamivudine + tenofovir & 19 & 8.3 \\
\hline Nevirapine + (zidovudine + lamivudine) & 18 & 7.9 \\
\hline Lamivudine + lopinavir/ritonavir + tenofovir & 15 & 6.6 \\
\hline Atazanavir + (zidovudine + lamivudine) & 12 & 5.2 \\
\hline Other therapies & 47 & 20,5 \\
\hline Total & $\mathbf{2 2 9}$ & $\mathbf{1 0 0 . 0}$ \\
\hline ART: antiretroviral therapy. & &
\end{tabular}

In $55.5 \%(\mathrm{n}=127)$ of cases, the patients used a combination of 2 reverse transcriptase inhibitors, nucleoside/nucleotide analogs (NRTIs) (zidovudine, lamivudine, tenofovir, stavudine, didanosine, or abacavir) and 1 non-nucleoside analog reverse transcriptase inhibitor (NNRTI) (efavirenz or nevirapine). The combination of 2 NRTIs and 2 protease inhibitors (PI) (lopinavir, ritonavir, atazanavir, saquinavir, or indinavir) was used in $28.8 \%$ $(n=69)$ of the therapies.

From the patients using the combination of $L V P / r$ AZT/3TC, $85 \%(\mathrm{n}=34)$ were considered to be receiving inadequate treatment (Table 3).

The majority of the patients $(n=159,66.4 \%)$ received AZT $/ 3$ TC in combination with another drug. The compliance for these drugs can be seen in Table 4.

Data analysis showed that when AZT/3TC was used, the patients adhered less to the therapy; however, when AZT or 3TC was used separately, it did not affect adherence. 
TABLE 3 - Distribution of patients who were undergoing ART and had inadequate treatment due to combination therapy.

\begin{tabular}{lrc}
\hline & \multicolumn{2}{c}{$\begin{array}{c}\text { Patients with inadequate } \\
\text { treatment }\end{array}$} \\
\cline { 2 - 4 } Treatment & $\mathbf{n}$ & $\%$ \\
\hline Lopinavir/ritonavir + (zidovudine + lamivudine) & 34 & 85.0 \\
\hline Atazanavir + (zidovudine + lamivudine) & 10 & 83.3 \\
\hline Efavirenz + (zidovudine + lamivudine) & 59 & 75.6 \\
\hline Nevirapine + (zidovudine + lamivudine) & 13 & 72.2 \\
\hline Efavirenz + lamivudine + tenofovir & 12 & 63.2 \\
\hline Lamivudine + lopinavir/ritonavir + tenofovir & 10 & 63.2 \\
\hline Others* & 64 & 61.7 \\
\hline Total & $\mathbf{1 6 7}$ & \\
\hline ART: antiretroviral therapy. ${ }^{*}$ drug combinations with a prescription administered \\
to <10 patients. & &
\end{tabular}

TABLE 4 - Patient adherence to ART containing AZT+3TC.

\begin{tabular}{|c|c|c|c|c|c|c|}
\hline & \multicolumn{2}{|c|}{$\begin{array}{l}\text { Adequate } \\
\text { treatment }\end{array}$} & \multicolumn{2}{|c|}{$\begin{array}{c}\text { Inadequate } \\
\text { treatment } \\
\end{array}$} & \multicolumn{2}{|c|}{ Total } \\
\hline & $\mathbf{n}$ & $\%$ & $\mathbf{n}$ & $\%$ & $\mathbf{n}$ & $\%$ \\
\hline $\mathrm{AZT}+3 \mathrm{TC}$ absent & 26 & 11.4 & 44 & 19.2 & 70 & 30.6 \\
\hline $\mathrm{AZT}+3 \mathrm{TC}$ present & 36 & 15.7 & 123 & 53.7 & 159 & 69.4 \\
\hline Total & 62 & 27.1 & 167 & 72.9 & 229 & 100.0 \\
\hline
\end{tabular}

ART: antiretroviral therapy; AZT: zidovudine; 3TC: lamivudine. $\chi^{2}: 4,468$ (with Yates correction for continuity); degrees of freedom: $1 ; \mathrm{p}=0.035 ; \mathrm{n}=229$.

\section{DISCUSSION}

With the increased life expectancy of HIV-positive patients after the development of ART $^{1}$, new challenges have emerged in an attempt to improve the quality of their lives. Among these new concerns is the need for their reintegration into society, the promotion of healthy habits, and the concern in making the patient and society understand the rights of HIV-positive persons with respect to their sexuality and parenthood. Furthermore, knowledge has to be provided about how to cope with the adverse effects of treatment, their adaptation to the treatment regimen, the continuous evaluation of infection, and properly treating co-infections such as hepatitis and tuberculosis ${ }^{10}$.

Data analysis in this study showed that out of the 229 patients, $63.8 \%$ were male and $36.2 \%$ female, i.e., 1.8 men for every woman. This finding supports the results of Carmody et al. ${ }^{11}$, Carrieri et al. ${ }^{12}$, Gomes et al. ${ }^{9}$, and Carvalho et al. ${ }^{13}$

The average age of the patients found in this study was $44.0 \pm$ 9.9 years, similar to the findings of Pinto Neto et al. ${ }^{14}(42.76 \pm 10.29$ years). However, Carrieri et al. ${ }^{12}$ and Carvalho et al. ${ }^{13}$ reported an average age of 37 years and 36.5 years, respectively, while Gomes et al. ${ }^{9}$ reported that $53.2 \%$ of their patients were younger than 35 years. These results reinforce the importance of local epidemiological studies, since knowledge of patient characteristics is crucial for effective health promotion campaigns.

It was observed that $72.9 \%(\mathrm{n}=167)$ of patients received inappropriate treatment, characterized by their irregular adherence to therapy or abandonment. This finding differs from those obtained by Saldanha, Andrade, and Beck ${ }^{15}$, who found a high rate of treatment adherence $(72 \%)$, and by Seidl et al. ${ }^{16}$, where the compliance rate reached $72.3 \%$. However, in these studies with high drug compliance, there was a pharmacist intervention, which, when the present study was performed, was not available at the participating health centers.

While this study did not find a significant difference in the evaluation of adherence to therapy by gender, Nachega et al. ${ }^{17}$ found a higher rate of adherence in women, while Carmody et al. ${ }^{11}$ found an association between non-adherence and female gender.

Although no association was observed between age group and adherence to therapy, we found that people aged younger than 30 years were more prone to irregular adherence or non-adherence to treatment (91.7\%). This finding is contrary to the literature, where it is observed that the higher the age, the higher the rate of adherence to therapy, with an age between 25 and 34 years considered as a risk factor for non-adherence ${ }^{17,18}$. However, we present a limitation of the current study here in that we did not know the income or the educational level of the patients, which probably influenced drug compliance, and the lack of this fit could be the cause for this absence of significance.

In this study, we found that 28 different drug combinations had been used for the study population. However, 6 combinations were used in $59.5 \%$ of patients, which showed that some treatments are prescribed more often than others. Most therapies were triple $(\mathrm{n}=18) ; 7$ consisted of 4 drugs and 2 with 5 combinations. Gir Vaichulonis and Oliveira ${ }^{19}$ found similar data, since $84.5 \%$ of their patients were using a regimen of up to 3 medications. Therapies involving a combination of more than 4 drugs are used in order to achieve immune rescue or as a resource for those patients whose treatment has already encountered some kind of resistance.

It was found that $55.5 \%$ of seropositive individuals were using a combination of 2 NRTIs and an NNRTI. This combination of a PI with 2 NRTIs, which was also clearly observed in this study, is a guideline of the Brazilian Ministry of Health for the initial therapy against $\mathrm{HIV}^{20}$. Furthermore, a combination of 2 NRTIs and 2 PIs was used in $28.8 \%$ of cases, in accordance with the guideline of the Ministry of Health, which states that when replacing an NNRTI, a PI should be used in combination with ritonavir, which is also a drug of the same class ${ }^{20}$.

The most common combination of 2 NRTIs and an NNRTI was AZT/3TC with EFV (34.1\%). Likewise, in the study of Gomes et al. ${ }^{9}, 30.7 \%$ of patients used this combination therapy. However, regarding the combination of 2 NRTIs and a PI, Gomes et al. ${ }^{9}$ found that $23.5 \%$ of patients used the combination of nelfinavir and AZT/3TC, whereas in the present study, lopinavir/ritonavir $(\mathrm{LPV} / \mathrm{r})$ combined with AZT/3TC was the most common NRTI-IP combination $(17.5 \%)$.

Carrieri et al. ${ }^{12}$ observed that the presence of a PI in combination therapy was one of the factors that influenced noncompliance. This might be explained by the fact that treatments without a PI are simpler and have less adverse effects than other therapies. However, Gomes et al. ${ }^{9}$ found significant results concerning combined therapy without a PI and non-adherence to treatment, contradicting the previous study. In the present study, those combinations containing LPV/r or ATV and AZT plus 3TC showed higher rates of inadequate treatment ( $85 \%$ and $83.3 \%$, respectively).

Among the pharmacological combinations analyzed ${ }^{5}$, they had a pair NRTI AZT/3TC between drugs used in the therapy. The use of AZT/3TC in the majority of the combinations in this study can be attributed to the fact that the Ministry of Health recommends 
it as the dual NRTI of choice for the initial treatment of HIV. This statement is possibly due to the numerous studies available on this drug combination, its toxicity, and its security level, and that fact that these drugs are also available as a co-formulation ${ }^{20}$ with a lower cost than other combinations of drugs of the same class 9 . However, when the AZT/3TC combination was used in therapy, we observed a significant increase in the number of patients who abandoned their treatment or showed irregular adherence. Although this combination has several advantages, the corresponding lack of adherence should be studied further in order to clarify if it really is suitable as a first choice therapy. Here, it was the most prevalent therapy and the only one that was associated with inadequate treatment.

The Ministry of Health recognizes that actions that improve adherence may be enhanced by strategies such as health information, compliance groups, and individual sessions, with a focus on adherence, referral, consultation, joint activities in the waiting room, café conversations, directly observed treatment, complementary practices, and civil society actions ${ }^{10}$.

It is important to consider that the initial period of clinical monitoring is critical and the link between the patient and the health team takes place very often through individual monitoring, social support, and guidance on the disease ${ }^{21}$.

Given this diagnosis, the pharmacist has a prominent and strategic role in supporting the treatment. The pharmacist is the professional who can guide the patient properly and also identify drug interactions and adverse reactions early on, thereby improving treatment adherence ${ }^{22}$. In this aspect, positive cases should be highlighted. A pharmacy-based ART adherence program, which included one-on-one visits with a clinical pharmacist, led to a $25 \%$ increase in the proportion of patients with a $\geq 95 \%$ adherence rate and an overall adherence rate of $21 \%$ over a 6 -month period ${ }^{23}$. After a 6-month pharmacist intervention, Ma et al. ${ }^{24}$ showed a clinically significant decrease in viral load, with $96 \%$ of patients able to achieve or maintain an undetectable HIV viral load. The pharmacist is responsible for the reduction in regimen complexity (measured by daily pill quantity and dosing frequency) that coincides with an improvement in medication adherence. A qualitative study by Yokaichia et al. ${ }^{25}$ reported that, specifically in Brazil, patients trust their pharmacist, and the pharmacy is a suitable place to report things that patients cannot discuss with their doctor. Other functions of the pharmacist, such as adjusting the times for administering medication according to the patient's lifestyle and to clarify possible side effects, can improve drug compliance.

Inadequate treatment (partial adherence) can cause drug resistance, thus limiting the availability of future effective drug regimens ${ }^{26}$. On the basis of the excellent results on drug compliance due to pharmaceutical care, the HU/CAS/UFJF recently created the Serviço de Informação Tóxico-Farmacológica (Office of Toxic-Pharmacological Information) (SINTOXFAR), which has a pharmacist to meet the demands of patients, conduct pharmacotherapeutic follow-up, and, within the context of a multidisciplinary approach, contribute significantly to treatment adherence and the improvement of patients living with HIV/AIDS.

The majority of patients in the present study received inadequate treatment. Therefore, it is necessary to implement strategies that improve treatment compliance in order to ensure therapeutic efficacy and to increase patients' quality of life and survival.

\section{CONFLICT OF INTEREST}

The authors declare that there is no conflict of interest.

\section{REFERENCES}

1. Oliveira OCA, Oliveira RA, Souza LR. Impacto do tratamento antirretroviral na ocorrência de macrocitose em pacientes com HIV/AIDS do município de Maringá, Estado do Paraná. Rev Soc Bras Med Trop 2011; 44:35-39.

2. Dourado I, Veras MASM, Barreira D, Brito AM. Tendências da epidemia de AIDS no Brasil após a terapia anti-retroviral. Rev Saude Publica 2006; 40 (supl):9-17.

3. Lignani Júnior L, Greco DB, Carneiro M. Avaliação da aderência aos antirretrovirais em pacientes com infecção pelo HIV/AIDS. Rev Saude Publica $2001 ; 35: 495-501$.

4. Ministério da Saúde. Programa Nacional de DST e AIDS. Boletim epidemiológico - AIDS e DST 2008. Brasília: Secretaria de Vigilância em Saúde Brasília; 2008.

5. Lima HMM. Adesão ao tratamento HIV/AIDS por pacientes com AIDS, Tuberculose e usuários de drogas de São Paulo [Doctos Thesis]. [São Paulo]: Universidade de São Paulo; 2006. 186 p.

6. Teixeira MG, Silva GA. A representação do portador do vírus da imunodeficiência humana sobre o tratamento com os antirretrovirais. Rev Esc Enferm/ Universidade de São Paulo 2008; 42:729-736.

7. Dias MK. Adesão medicamentosa em AIDS: interferência de variáveis sociodemográficas, psicossociais e psicopatológicas [Dissertation]. [Campinas]: Universidade Estadual de Campinas; 2002. 156 p.

8. Faustino QM, Seidl EMF. Intervenção cognitivo-comportamental e adesão ao tratamento em pessoas com HIV/Aids. Psic: Teor e Pesq 2010; 26:121-130.

9. Gomes RRFM, Machado CJ, Acurcio FA, Guimarães. Utilização dos registros de dispensação da farmácia como indicador da não-adesão à terapia antirretroviral em indivíduos infectados pelo HIV. Cad Saude Publica 2009; 25:495-506.

10. Ministério da Saúde. Programa Nacional de DST e AIDS. Diretrizes para o fortalecimento das ações de adesão ao tratamento de pessoas que vivem com HIV e AIDS. Brasília: Secretaria de Vigilância em Saúde; 2007.

11. Carmody ER, Diaz T, Starling P, Santos AP, Sacks HS. An evaluation of antiretroviral HIV/AIDS treatment in a Rio de Janeiro public clinic. Trop Med Int Health 2003; 8:378-385.

12. Carrieri MP, Leport C, Protopopescu C, Cassuto JP, Bouvet E, Peyramond $\mathrm{D}$, et al. Factors associated with nonadherence to highly active antiretroviral therapy: a 5-year follow-up analysis with correction for the bias induced by missing data in the treatment maintenance phase. J Acquir Immune Defic Syndr 2006; 41:477-485.

13. Carvalho CV, Duarte DB, Merchán-Hamann E, Bicudo E, Laguardia J. Determinantes da aderência à terapia antirretroviral combinada em Brasília, Distrito Federal, Brasil, 1999-2000. Cad Saude Publica 2003; 19:593-604.

14. Pinto Neto LFS, Braga AC, Rocha JA, Vieira NFR, Miranda AE. Fatores de risco associados a alterações renais em pacientes infectados por HIV-1. Rev Soc Bras Med Trop 2011; 44:30-34.

15. Saldanha JS, Andrade CS, Beck ST. Grau de adesão ao tratamento com antirretrovirais entre indivíduos HIV positivos atendidos no Hospital Universitário de Santa Maria. Saúde Santa Maria 2009; 35:4-9.

16. Seidl EMF, Melchíades A, Farias V, Brito A. Pessoas vivendo com HIV/AIDS: variáveis associadas à adesão ao tratamento antirretroviral. Cad Saude Publica. 2007; 23: 2305-2316.

17. Nachega JB, Hislop M, Dowdy DW, Lo M, Omer SB, Regensberg L, et al. Adherence to highly active antiretroviral therapy assessed by pharmacy claims predicts survival in HIV-infected South african adults. J Acquir Immune Defic Syndr 2006; 43:78-84.

18. Brito AM, Szwarcwald CL, Castilho EA. Fatores associados à interrupção de tratamento antirretroviral em adultos com AIDS: Rio Grande do Norte, Brasil, 1999-2002. Rev Assoc Med Bras 2006; 52:86-92.

19. Gir E, Vaichulonis CG, Oliveira MD. Adesão à terapêutica anti-retroviral por indivíduos com HIV/AIDS assistidos em uma instituição do interior paulista. Rev Lat Am Enfermagem 2005; 13:634-641. 
20. Ministério da Saúde. Programa Nacional de DST e AIDS. Recomendações para a terapia antirretroviral em adultos infectados pelo HIV. $7^{\text {th }}$ ed. Brasília: Secretaria de Vigilância em Saúde; 2008.

21. Ministério da Saúde. Departamento de DST, Aids e hepatites virais. Adesão ao tratamento antirretroviral no Brasil: coletânea de estudos do projeto atar. Brasília: Secretaria de Vigilância em Saúde; 2010.

22. Ministério da Saude. Departamento de DST, Aids e hepatites virais. Protocolo de assistência farmacêutica em DST/HIV/Aids: recomendações do Grupo de Trabalho de Assistência Farmacêutica. Brasília: Secretaria de Vigilância em Saúde; 2010

23. Henderson KC, Hidman J, Johnson SC, Valuck RJ, Kiser JJ. Assessing the effectiveness of pharmacy-based adherence interventions on antiretroviral adherence in persons with HIV. AIDS Patient Care STDs 2011; 25:221-228.

24. Ma A, Chen DM, Chau FM, Saberi P. Improving adherence and clinical outcomes through an HIV pharmacist's interventions. AIDS Care 2010; 22:1189-1194.

25. Yokaichiya CM, Figueiredo WS, Schraiber LB. Injecting drug users and antiretroviral therapy: perceptions of pharmacy teams. Rev Saude Publica 2007; 41:1-7.

26. Hirsch JD, Gonzales M, Rosenquist A, Miller TA, Gilmer TP, Best BM. Antiretroviral therapy adherence, medication use, and health care costs during 3 years of a community pharmacy medication therapy management program for medical beneficiaries with HIV/AIDS. J Manag Care Pharm 2011; 17:213-223. 